Jurnal Widya Laksana, Vol.11, No.1, Januari 2022

\title{
PENINGKATAN KETERAMPILAN MENULIS KREATIF BERMUATAN PENDIDIKAN BUDI PEKERTI PADA GURU-GURU SEKOLAH DASAR MELALUI HYBRID LEARNING
}

\author{
Retno Winarni ${ }^{1}$, St. Y. Slamet ${ }^{2}$, Jenny IS Poerwanti ${ }^{3}$, Muhammad Ismail \\ Sriyanto $^{4}$, Septi Yulisetiani ${ }^{5}$, Ahmad Syawaludin ${ }^{6}$ \\ 1,2,3,4,5,6 FKIP, Universitas Sebelas Maret \\ e-mail: retnowinarni@staff.uns.ac.id, st_ys@staff.uns.ac.id, jenny_isp@staff.uns.ac.id, \\ ismail48@staff.uns.ac.id, septi.yulisetiani@staff.uns.ac.id, syawaluns@gmail.com
}

\begin{abstract}
Abstrak
Kegaiatan pengabdian ini bertujuan untuk meningkatkan kemampuan menulis kreatif bermuatan pendidikan budi pekerti pada guru SD melalui pelatihan tatap muka dan virtual. Subjek pengabdian ini adalah guru-guru SD sebanyak 13 orang, terdiri atas guru kelas satu sampai dengan kelas enam. Metode partisipatif digunakan dalam pelatihan ini guna menstimulasi para guru untuk aktif dalam berlatih menulis puisi baik teori dan praktik. Pertemuan tatap muka dilakukan sebanyak dua kali untuk pelatihan teori, adapun pertemuan virtual dilakukan dalam kegiatan pelatihan praktik menulis puisi dan mempresentasikannya. Berdasarkan hasil penskoran kemampuan menulis puisi pada sesi posttes diperoleh kemampuan klasikal dalam menulis puisi sebesar $84,90 \%$ dimana pada tahap pretes adalah 70,79\%. Hasil menunjukkan bahwa pelatihan menulis puisi bermuatan Pendidikan budi pekerti melalui metode campuran tatap muka dan virtual (Hybrid Learning) mampu meningkatkan kemampuan para guru SD dalam menulis kreatif jenis puisi. Peningkatan kemampuan menulis puisi pada peserta terlihat pada seluruh aspek menulis puisi, mencakup tema dan makna, kekuatan imajinasi, ketepatan diksi, dan amanat.
\end{abstract}

Kata kunci: menulis kreatif, puisi, pendidikan karakter, guru sekolah dasar

\begin{abstract}
This service activity aims to improve creative writing skills with character education for elementary school teachers through face-to-face and virtual training. The subjects of this service are elementary school teachers as many as 13 teachers, consisting of grade one to six grade. The participatory method was used in this training to stimulate teachers to be active in practicing poetry writing both in theory and practice. Face-to-face meetings were held twice for theoretical training, while virtual meetings were held for practical training in writing poetry and presenting it. Based on the results of scoring the ability to write poetry in the posttest session, the classical ability in writing poetry was $84.90 \%$, where at the pretest stage it was $70.79 \%$. The results show that poetry writing training containing character education through a mixed face-toface and virtual method (Hybrid Learning) is able to improve the ability of
\end{abstract}


elementary school teachers in writing creative poetry types. The improvement in the poetry writing skills of the participants was seen in all aspects of writing poetry, including themes and meanings, the power of imagination, accuracy of diction, and the message.

Keywords: creative writing, poetry, character education, elementary school teacher

\section{PENDAHULUAN}

Sebagai salah satu keterampilan berbahasa, menulis merupakan aspek penting yang dibelajarkan kepada peserta didik di sekolah dasar. Menulis merupakan cara seseoarang mengungkapkan ide, pikiran, perasaan kepada orang lain secara tertulis (Angreany \& Saud, 2017). Kemampuan menulis memiliki peran penting dan menjadi hal yang tidak dapat terpisahkan dari kegiatan belajar siswa, serta aplikasi dalam kehidupan seharihari (Gurning, 2021; Dibia et al., 2017). Keterampilan menulis merupakan keterampilan berbahasa yang dikuasai setelah menyimak, berbicara, dan membaca. Keterampilan menulis sebagai keterampilan produktif yang menghasilkan sebuah karya dalam bentuk tulisan sehingga banyak yang menyebutkan bahwa keterampilan menulis tidak mudah dan perlu latihan, termasuk dalam menulis kreatif (Pertiwi \& Kolen, 2020; Lubis, 2017).

Menulis kreatif merupakan wujud ekspresi pikiran dan mengaktifkan imajinasi dapat dikembangkan. Menulis kreatif identic dengan pengembangan ide penulis dan imajinasi atas pengalaman yang dimiliki sehingga menghasilkan tulisan yang indah (Nurrachman \& Ratnaningsih, 2019; Saraswati, 2014). Menulis kreatif adalah menulis yang ditujukan untuk menyampaikan ide, perasaan, dan emosi bukan sekedar menyampaikan informasi saja (Anggraeni, 2017). Oleh karena itu, pembelajaran keterampilan menulis kreatif perlu berfokus pada cara menuangkan ide yang dimiliki siswa ke dalam bentuk tulisan. Menulis kreatif berperan dalam pengembangan potensi kognitif maupun kreatif siswa karena siswa berupaya dalam menuangkan pengalaman, pengetahuan, dan perasaan yang membutuhkan daya imajinasi dan kreativitas agar tulisan yang dibaca menjadi indah dan bermakna (Arsanti, 2018; Wardiyah, 2017).

Salah satu pembelajaran menulis kreatif di sekolah dasar diimplementasikan dalam pembelajaran manulis puisi. Menulis puisi merupakan bagian yang terkandung pada sastra yang dapat membantu mengembangkan keterampilan menulis dan daya imajinasi, serta mampu mengapresiasi karya sastra. Menulis puisi melibatkan proses penggalian ide, pemilihan tema, pemilihan diksi, pemilihan permainan bunyi (rima), pemanfaatan gaya bahasa. Oleh karena itu, guru memiliki peran penting dalam menentukan keberhasilan belajar siswa dalam menulis puisi. Guru dapat mendorong siswa dalam mengasah dan meningkatkan keterampilan (Muhajir et al., 2021). Guru juga berperan sebagai fasilitator dengan memberikan rasa 
senang pada siswa, dan mengevaluasi hasil karya puisi siswa (Safitri \& Dafit, 2021). Dengan demikian, penguasaan guru terhadap menulis puisi baik teori dan praktik merupakan hal yang penting.

Pentingnya kemampuan menulis kreatif di sekolah dasar belum diimbangi dengan hasil menulis kreatif yang baik (Anggraeni, 2017), misalnya dalam pembelajaran menulis puisi. Studi awal yang dilakukan oleh tim pengabdian pada siswa di sekolah dasar negeri di kota Surakarta menunjukkan adanya hasil menulis kreatif yang belum menggembirakan. Pembelajaran menulis puisi menjadi salah kesulitan siswa. Unsur-unsur menulis puisi, pemilihan diksi, dan mencari ide serta menuangkannya dalam bentuk tulisan puisi menjadi faktor-faktor yang ternyata belum banyak dikuasai oleh guru. Kurang piawainya guru dalam menulis kreatif memberi kelemahan kompetensi profesional guru sehingga turut berimbas pada pembelajaran menulis kreatif yang tidak maksimal. Dengan demikian, maka penguatan kompetensi guru dalam menulis kreatif perlu dilakukan.

Berpijak dari permasalahan yang dialami oleh para guru, tim pengabdian dari PGSD FKIP UNS menawarkan solusi melalui pelatihan dan pendampingan menulis kreatif berbasis pendidikan budi pekerti pada guru-guru SD di salah satu sekolah dasar di Kota Surakarta. Pemilihan kajian menulis puisi bermuatan pendidikan karakter berangkat dari hakikat puisi sebagai sastra. Puisi memiliki peran dalam implementasi pendidikan budi pekerti yang saat ini menjadi prioritas pemerintah sebagaimana dalam ketentuannya ada pada kurikulum 2013. Jika dikontekskan dengan abad 21 ini di mana dunia tengah memasuki era global, pendidikan yang mengarah pada pembentukan karakter kebangsaan sangat urgen dilakukan (Arsini, 2021; Amelia \& Dhita, 2020; Desrani \& Adnani, 2020). Melalui menulis dan membaca puisi, seseorang dapat menggali nilai kearifan lokal sebagai pembentuk karakter kebangsaan. Melalui pembelajaran puisi, siswa akan mengenal ragam karya sastra yang penuh dengan nilainilai budaya bangsa. Kaitannya dengan itu, pembentukan karakter siswa di sekolah dapat dilakukan melalui pembelajaran sastra (Aminin et al., 2018).

Pelatihan menulis kreatif bermuatan pendidikan karakter pada pengabdian ini merujuk pada delapan belas karakter yang ada pada kurikulum 2013, mencakup (1) religius, (2) jujur, (3) toleransi, (4) disiplin, (5) kerja keras, (6) kreatif, (7) mandiri, (8) demokratis, (9) rasa ingin tahu, (10) semangat kebangsaan, (11) cinta tanah air, (12) menghargai prestasi, (13) bersahabat/komunikatif, (14) cinta damai, (15) gemar membaca, (16) peduli lingkungan, (17) peduli sosial, (18) tanggung jawab (Fatriyah et al., 2020; Marzuki \& Hakim, 2019). Adapun pada kegiatan pengabdian ini para peserta diarahkan pada pemilihan tema karakter dari delapan belas karakter di atas, terdiri atas karakter toleransi, semangat kebangsaan, cinta tanah air, dan cinta damai. Pemilihan tema ini dipandang perlu mengingat pada jenjang sekolah dasar pembentukan karakter yang mengarah pada stabilitas 
kehidupan bernegara yang multikultural sangat diperlukan.

Kurikulum yang digunakan di sekolah mitra pengabdian adalah kurikulum 2013. Terdapat satu ruang baca perpusakaan, sehingga cukup memberikan ruang bagi siswa untuk melakukan aktivitas yang berkaitan dengan literasi. Kontribusi pengabdian ini diharapkan dapat menfasilitasi para guru dalam menulis karya kreatif berbasis pendidikan budi pekerti.

\section{METODE}

Subjek atau peserta pengabdian dalam kegiatan pengabdian ini adalah 13 orang guru SD. Para guru yang dipilih adalah guru kelas bawah dan kelas atas. Adapun sasaran program pengabdian ini adalah peningkatan kemampuan guru dalam menulis kreatif bermuatan nilai pendidikan budi pekerti di sekolah dasar. Metode yang digunakan dalam kegiatan PKM ini adalah partisipatif, yaitu menekankan pada proses pembelajaran, di mana kegiatan belajar dalam pelatihan dibangun atas dasar partisipasi aktif (keikutsertaan) peserta pelatihan dalam semua aspek kegiatan pelatihan. Alur pengabdian ini dilaksanakan dengan tahapan sebagai berikut: (1) Identifikasi Kebutuhan dan Tingkat Kebutuhan; (2) Identifikasi Faktor Pendukung dan Sumber Daya; (3) Merumuskan Tujuan Pelatihan; (4) Memilih dan Menetapkan Isi dan Muatan; (5) Memilih Metode pelatihan (Ceramah, diskusi, penugasan); (6) Evaluasi Program Pelatihan.

Dalam pelaksanannya, pengabdian ini akan dilaksanakan secara tatap muka dan secara online.
Pertemuan secara tatap muka akan dilaksanakan sebanyak dua kali dengan kegiatan: pemaparan materi, analisis silabus dan RPP, serta diskusi kelompok kecil untuk pemilihan tema, jenis tulisan, dan penggalian ide. Adapun untuk pelaksanaan online dilakukan sebanyak dua kali dengan agenda adalah monitoring progres menulis puisi dan pembacaan puisi serta apresiasi puisi yang telah ditulis para peserta. Pertemuan tatap muka dilakukan dengan memperhatikan perkembangan kebijakan pemerintah terkait penanganan kasus covid-19. Adapun pertemuan secara online dilaksanakan melalui google meet.

Indikator keberhasilan program pengabdian ini berpedoman pada aspek-aspek menulis puisi (mencakup tema, isi, diksi, rima) beserta menilai orisinalitas karya dan kemampuan penulis dalam pengekspresikan gagasan atau ide yang bermuatan nilainilai pendidikan budi pekerti. Indikator yang ditargetkan pada kegiatan pengabdian ini adalah $80 \%$ para peserta memperoleh skor menulis puisi di atas 75 .

\section{HASIL DAN PEMBAHASAN}

Kegiatan pengabdian ini diawali dengan pelatihan kepada peserta didik dengan menyajikan (1) Konsep sastra dan pembelajaran sastra di sekolah dasar; (2) pengkajian sastra puisi; (3) Keterampilan menulis kreatif (Konsep, ragam, karakteristik, dan aspek-aspek menulis kreatif); (4) Menulis kreatif berbasis pendidikan budi pekerti (termasuk karakter prioritas Program Pendidikan Karakter). Karya yang ditulis oleh masing-masing peserta secara praktek menulis sastra puisi 
Jurnal Widya Laksana, Vol.11, No.1, Januari 2022

berbasis pendidikan budi pekerti (termasuk karakter prioritas Program Pendidikan Karakter). Pendampingan bagi para guru dalam menulis kreatif berbasis pendidikan budi pekerti dilaksanakan melalui virtual dengan memanfaatkan aplikasi google meet.

Melalui metode observasi diketahui bahwa para guru tertarik dalam mengikuti pelatihan. Hal ini terlihat dari aktivitas guru selama pelatihan secara aktif mengajukan pertanyaan, membuka diskusi, dan memberikan tanggapan atas pertanyaan yang diberikan oleh narasumber maupun kepada peserta lain. Sebagian guru melaporkan bahwa banyak hal baru yang mereka ketahui tentang unsur-unsur menulis puisi secara lebih spesifik. Penguasaan konsep puisi dan pembelajaran menulis puisi dilanjutkan dengan praktik menulis yang dilaksanakan dengan waktu terpisah. Para peserta diberikan waktu selama satu minggu dalam membuat puisi bermuatan pendidikan budi pekerti. Karya-karya puisi yang ditulis oleh peserta selanjutnya dianalisis berdasarkan pada unsur-unsur menulis puisi yang dikembangkan dari pendapat Nurgiyantoro (2012) dalam Izhar (2017). Perolehan skor kemampuan menulis puisi bermuatan pendidikan budi pekerti disajikan pada Tabel 1 .

Tabel 1. Perolehan Skor Kemampuan Menulis Puisi Peserta Pelatihan

\begin{tabular}{llcc}
\hline \multirow{2}{*}{ No } & \multicolumn{1}{c}{ Aspek } & \multicolumn{2}{c}{ Skor (\%) } \\
\cline { 3 - 4 } & Tema dan Makna & 74,77 & Postest \\
\hline 1 & Kekuatan Imajinasi & 66,69 & 86,54 \\
3 & Ketepatan Diksi & 65,08 & 83,23 \\
4 & Amanat & 76,62 & 82,85 \\
\hline \multicolumn{2}{c}{ Rata-rata } & 70,79 & 87,00 \\
\hline
\end{tabular}

Berdasarkan table 1 dapat diketahui secara umum kemampuan para peserta pelatihan meningkat dari sebelum pelatihan dan setelah pelatihan. Pada aspek tema dan makna para pretes ditemukan Sebagian besar guru sudah baik dalam memilih tema yang sesuai dengan dikaitkan pada nilai-nilai Pendidikan budi pekerti yang akan disampaikan kepada pembaca. Meskipun demikian, para guru masih kesulitan dalam memilih diksi yang tepat. Hal ini terlihat dari pilihan kata yang ditulis guru dalam satu bangunan karya puisi masih kurang tepat. Perbaikan dilakukan melalui kegiatan pertemuan virtual melalui google meet antara peserta dengan narasumber.

Pada aspek imajinasi, para peserta di awal pelatihan sudah menunjukkan ragam ide yang baru dan relevan dengan dunia anak terkini. Seperti masuknya peran teknologi digital hingga ide-ide terkait dengan fenomena pandemi covid. Pesan-pesan yang disampaikan melalui puisi juga sudah memuat Pendidikan budi pekerti. Aspek amanat ini menjadi aspek 
tertinggi yang dikuasai oleh peserta pelatihan.

Setelah mengikuti pelatihan secara teori, para guru diberikan kesempatan untuk memilih tema berdasar nilai-nilai Pendidikan budi pekerti yang dimuat pada kurikulum Pendidikan nasional. Hasil karya guru kemudian dibacakan secara virtual melalui google meet dan dibahas secara Bersama tentang makna puisi yang dibuat. Pembahasan karya peserta pelatihan sekaligus menstimulasi para peserta lainnya untuk mengapresiasi salah satu jenis sastra tersebut.

Perolehan hasil postest selanjutnya ditemukan rerata yang menunjukkan perolehan klasikal sudah mencapai lebih dari 80 persen, yakni indikator keberhasilan pelatihan. Setiap aspek menulis ditemukan sudah meningkat menjadi lebih dari $80 \%$. Hasil pelatihan menulis puisi ini menguatkan temuan bahwa perlunya pelatihan tentang menulis puisi. Ragam cara dilakukan dalam upaya meningkatkan kemampuan menulis puisi, seeperti melalui pembinaan minat sastra anak melalui pelatihan menulis puisi bebas dengan aksara arab melayu (Idawati et al., 2021); pelatihan menulis puisi dengan media gambar (Nalenan, 2020); pelatihan menulis puisi dengan deret kata di Bandar Lampung (Maryova et al., 2019); pelatihan virtual menulis puisi di masa pandemi COVID-19 di Indramayu (Emha et al., 2020); dan peningkatan keterampilan menulis puisi berbasis pendidikan karakter menggunakan teknik kata kunci (Astuty et al., 2021).

Berdasarkan hasil penskoran kemampuan menulis puisi pada sesi posttes menunjukkan bahwa pelatihan menulis puisi bermuatan Pendidikan budi pekerti melalui metode campuran tatap muka dan virtual (Hybrid Learning) mampu meningkatkan kemampuan para guru SD di Kota Surakarta dalam menulis kreatif jenis puisi. Peningkatan kemampuan menulis puisi pada peserta terlihat pada seluruh aspek menulis puisi, mencakup tema dan makna, kekuatan imajinasi, ketepatan diksi, dan amanat.

\section{KESIMPULAN}

Hasil penelitian menggambarkan
bahwa adanya peningkatan kemampuan menulis puisi bermuatan pendidikan budi pekerti pada guru setelah mengikuti pelatihan yang dilakukan secara tatap muka dan virtual. Peningkatan kemampuan menulis ditinjau dari keseluruhan aspek menulis puisi yang mencakup tema dan makna, kekuatan imajinasi, ketepatan diksi, dan amanat. Dengan demikian dapat disimpulkan bahwa pelatihan menulis puisi melalui hybrid learning dapat meningkatkan kemampuan menulis puisi bermuatan pendidikan budi pekerti pada guru-guru SD di Kota Surakarta. Kontribusi penelitian ini bagi para guru dalam meningkatkan kemampuan menulis puisi, baik teori dan praktik.

\section{DAFTAR PUSTAKA}

Amelia, Z. Y., \& Dhita, A. N. (2020). Full day school sebagai strategi penguatan pendidikan karakter dalam era globalisasi. Jurnal Nalar Pendidikan, 8(1), 1-8.

Anggraeni, K. (2017). Efektivitas Model Menulis Kolaborasi Dengan 
Media Big Book Terhadap Keterampilan Menulis Kreatif. Jurnal Cakrawala Penda, 3(2).

Angreany, F., \& Saud, S. (2017). Keefektifan Media Pembelajaran Flashcard Dalam Keterampilan Menulis Karangan Sederhana Bahasa Jerman Siswa Kelas Xi Ipa Sma Negeri 9 Makassar. Eralingua: Jurnal Pendidikan Bahasa Asing dan Sastra, 1(2).

Arsanti, M. (2018). Pengembangan bahan ajar mata kuliah penulisan kreatif bermuatan nilai-nilai pendidikan karakter religius bagi mahasiswa prodi PBSI, FKIP, UNISSULA. KREDO: Jurnal Ilmiah Bahasa dan Sastra, 1(2), 69-88.

Arsini, N. W. A. (2021). Eksistensi satua bali sebagai media pendidikan karakter siswa di sd negeri 10 pedungan, denpasar selatan. VIDYA SAMHITA: Jurnal Penelitian Agama, 6(2).

Astuty, A., Farikah, F., \& Ekawati, M. (2021).

Peningkatan keterampilan menulis puisi berbasis pendidikan karakter menggunakan teknik kata kunci. Indonesian Journal of Education and Learning, 4(2), 494-499.

Desrani, A., \& Adnani, K. (2020). Pendidikan Karakter Dalam Program Asrama Bahasa Arab Menghadapi Era Revolusi Industri 4.0 $\mathrm{Di}$ Man 3 Palembang. KoPeN: Konferensi Pendidikan Nasional, 2(1), 4247.
Dibia, I. K., Dewantara, I. P. M., \& Widiana, I. W. (2017). Pemberdayaan Teknik Bercerita Berbasis Budaya Bali Dalam Pembelajaran Keterampilan Menulis Karangan Pribadi Siswa Kelas V SD Mutiara Singaraja. Journal of Education Research and Evaluation, 1(2), 113-119.

Emha, R. J., Abdullah, V. A., Pujiati, T., \& Iskandari, Y. (2020). Pelatihan virtual menulis puisi di masa pandemi COVID-19 untuk meningkatkan budaya literasi di SMP negeri 1 karangampel kab. indramayu. Abdi Laksana: Jurnal Pengabdian Kepada Masyarakat, 1(3), 331-335.

Fatriyah, F., Prasetyo, S. A., \& Ardiyanto, A. (2020). Daya Tangkap Siswa Terhadap Pesan Moral Dan Nilai Karakter Pada Film Animasi Moana. Jurnal IImiah Pendidikan Profesi Guru, 3(2), 303-310.

Gurning, E. O. (2021). Upaya Meningkatkan Keterampilan Menulis Cerpen Melalui Metode Latihan Terbimbing Dengan Media Teks Lagu Pada Siswa Kelas XII MIA-1 SMA Negeri 16 Medan. Cybernetics: Journal Educational Research and Social Studies, 151-160.

Idawati, I., Hasibuan, N. S., \& Nurkholija, A. (2021). Pembinaan minat sastra anak melalui pelatihan menulis puisi bebas dengan aksara arab melayu di mdta muhammadiyah sigiring giring dan mdta muhammadiyah sadabuan. 
Jurnal Widya Laksana, Vol.11, No.1, Januari 2022

Aptekmas: Jurnal Pengabdian Kepada Masyarakat, 4(2).

Izhar, I. (2017). Peningkatan Kemampuan Menulis Puisi dengan Menggunakan Model Pembelajaran Inkuiri pada Siswa Kelas IV MIN 4 Bengkulu Tengah. Diksa: Pendidikan Bahasa dan Sastra Indonesia, 3(1), 12-23.

Lubis, S. S. W. (2017). Keterampilan menulis essai dalam pembentukan berpikir kritis mahasiswa prodi PGMI UIN ArRaniry Banda Aceh. PIONIR: Jurnal Pendidikan, 6(2).

Maryova, F., Anggraini, T. R., \& Hastuti, H. (2019). Pelatihan Menulis Puisi dengan Deret Kata di SMA Perintis 2 Bandar Lampung. Adiguna: Jurnal Pengabdian dan Pemberdayaan Masyarakat, 4(1), 11-14.

Marzuki, I., \& Hakim, L. (2019). Strategi Pembelajaran Karakter Kerja Keras. Rausyan Fikr: Jurnal Pemikiran dan Pencerahan, 15(1).

Muhajir, M., Fatimah, M., \& Rohmah, R. (2021). Peningkatan Keterampilan Menulis Puisi Siswa Kelas VIII SMP Al Falah Pacul Bojonegoro dengan Model Pembelajaran Examples Non Examples. Attanwir: Jurnal Keislaman dan Pendidikan, 12(1), 115-123.

Nalenan, J. S. (2020). Pelatihan Menulis Puisi Dengan Media Gambar Pada Siswa Kelas VII SMP Negeri Kota Baru
Kefamenanu. Bakti Cendana, 3(2), 92-98.

Nurgiyantoro, B. (2012). Penilaian Pembelajaran Bahasa. Yogyakarta: Gadjah Mada University Press

Nurrachman, D., \& Ratnaningsih, S. R. (2019). Memfungsikan Imajinasi: Sosialisasi Menulis Kreatif Menggunakan Wordless Book pada Murid Kelas IX di MTs GUPPI Cileuksa, Desa Legok Kaler Kec. Paseh Kab. Sumedang. Al-Khidmat, 2(2), 36-42.

Pertiwi, S., \& Kolen, K. V. (2020). Pengaruh Media Film Terhadap Keterampilan Menulis Narasi Pada Mata pelajaran Bahasa Indonesia Pada Siswa Kelas V SD 02 Pagi Cipayung. Jurnal Inovasi Pendidikan $\mathrm{MH}$ Thamrin, 4(1), 10-19.

Safitri, V., \& Dafit, F. (2021). Peran Guru Dalam Pembelajaran Membaca Dan Menulis Melalui Gerakan Literasi Di Sekolah Dasar. Jurnal Basicedu, 5(3), 1356-1364.

Wardiah, D. (2017). Peran Storytelling dalam Meningkatkan Kemampuan Menulis, Minat Membaca dan Kecerdasan Emosional Siswa. Wahana Didaktika: Jurnal IImu Kependidikan, 15(2), 42-56. 